\title{
O Českém finančním a účetním časopisu a o výzkumném záměru Rozvoj účetní a finanční teorie a její aplikace $\mathrm{z}$ interdisciplinárního hlediska
}

Vážený čtenáři,

Český finanční a účetní časopis, jehož první číslo v prvním roce jeho života právě ted' otevíráte, se zaměřuje na publikování odborných článků s finanční a účetní tématikou. Cílem redakční rady je uveřejňovat výsledky výzkumu a vývoje z oblasti auditingu, bankovnictví, daní a veřejných financí, financí podniku, finančního účetnictví, manažerského účetnictví, měnové teorie a politiky, oceňování podniku a pojištovnictví. Finanční teorie prošla v minulých letech ohromným vývojem a zpětně ovlivnila finanční praxi. Účetní teorie se dnes zaměřuje na mezinárodní harmonizaci účetnictví a hledá cesty, jak reagovat na nové podněty, kterými se v poslední době stala především série bankrotů velkých nadnárodních společností. Mnohé tradiční postuláty obou teorií byly zdiskreditovány a je proto třeba najít jiná teoretická řešení starších problémů. Mimoto se objevují i nové problémy, o kterých dosavadní teorie ještě neuvažovala. Redakční rada proto věří, že Český finanční a účetní časopis může přinést k rozvoji účetní i finanční teorie nové poznatky a nová řešení. Aby jsme zajistili vydávání pouze kvalitních článků, podléhají všechny zaslané články redakci náročnému oponentnímu řízení.

Český finanční a účetní časopis obsahuje tři rubriky. V rámci rubriky Diskuse chceme přinášet odbornou polemiku $\mathrm{k}$ významným článkům uveřejněným v prestižních finančních a účetních časopisech a věříme, že tato diskuse může následně pokračovat v dalším výzkumu. V rubrice Recenze chceme seznamovat odbornou veřejnost s novými knižními publikacemi z finanční a účetní oblasti vydávanými jak v České republice, tak v zahraničí. Poslední rubrika Informace bude uveřejňovat informace např. z vědeckých konferencí, $\mathrm{z}$ odborných stáží nebo o výuce finanční a účetní problematiky.

Český finanční a účetní časopis je vydáván v kombinované tištěné a elektronické podobě. Nyní tedy nejspíš očekáváte informaci o tom, jak je možné tento časopis koupit. Musím Vás bohužel zklamat. Časopis není možné koupit. V tištěné podobě je vydáváno jen několik málo výtisků, které jsou určeny převážně do knihoven. Časopis si sice není možné koupit, ale lze si v něm kdykoli listovat a číst všechny články, nebot' elektronická podoba časopisu je př́istupná zdarma na internetových stránkách

\section{<http://cfuc.vse.cz>.}

Články jsou na internet umístěny v pdf formátu. Současně zde naleznete i pokyny pro autory, vzorový př́spěvek, formulář licenční smlouvy a stručný profill členů redakční rady.

Český finanční a účetní časopis vydává Vysoká škola ekonomická v Praze. O jejím postavení mezi ostatními vysokými školami s ekonomickým zaměřením nejlépe svědčí počty studenti̊. K 31. prosinci 2005 studovalo na naší škole 15766 studentů, z toho 9221 studentů v bakalářském studijním programu, 3319 studentů v magisterském studijním programu, 2483 v magisterském navazujícím studijním programu, 743 studentů v doktorském studijním programu. Velmi významné postavení zaujímá Vysoká škola ekonomická v Praze i v rámci 
výzkumu a vývoje ekonomických vědních disciplín. Na jejích pracovištích se řeší celá řada významných projektů a výsledky výzkumu jsou zveřejňovány v prestižních domácích a cizích časopisech.

Český finanční a účetní časopis je časopis vydávaný v rámci řešení výzkumného záměru Rozvoj účetní a finanční teorie a její aplikace v praxi z interdisciplinárního hlediska. Dovolte mi proto, abych Vám tento výzkumný projekt blíže představil. V roce 2004 se Fakulta financí a účetnictví Vysoké školy ekonomické v Praze úspěšně zúčastnila veřejné soutěže vyhlášené Ministerstvem školství, mládeže a tělovýchovy České republiky na nové výzkumné záměry s termínem zahájení od 1. ledna 2005. Předložený výzkumný záměr byl přijat s dobou řešení od 1. ledna 2005 do 31. prosince 2011. Př́ijemcem institucionální podpory na výzkumný záměr je Vysoká škola ekonomická v Praze, v roli vykonavatele projektu vystupuje Fakulta financí a účetnictví a mně připadla ta čest být hlavním řešitelem. Rešitelský tým tvoří celkem 8 profesorů, 8 docentů a 27 odborných asistentů.

Základní cíl výzkumného záměru spočívá $\mathrm{v}$ propojení jednotlivých úrovní vědeckého výzkumu od základního výzkumu založeného na převážně modelovém řešení nákladů zastoupení přes stanovení výchozích teoretických postulátů a tvorbu finanční a účetní metodiky, k aplikovanému výzkumu spočívajícímu ve třech oblastech: v práci na národních i mezinárodních účetních a oceňovacích standardech; $\mathrm{v}$ empirických studiích týkajících se vývoje finančních a účetních veličin v ČR a v dalších zemích; a ve zpracování modelů informačního řízení a finanční rozhodování v podnikové sféře.

Z organizačního hlediska je řešitelský tým rozdělen na čtyři pracovní skupiny. První pracovní skupina Základní výzkum (vedoucí: doc. Ing. Petr Marek, CSc.) se zabývá vypracováním teoretických postulátů pro finanční a účetní teorii sohledem na změny v probíhající mezinárodní harmonizaci účetnictví a současně pracuje na konstrukci modelu nákladů zastoupení, který by zahrnul hlavní agenty a principály v českém ekonomickém, politickém a sociální prostředí.

Druhá skupina Finanční účetnictví (vedoucí: prof. Ing. Libuše Müllerová, CSc.) se skládá dále z pěti pracovních podskupin. První podskupina Mezinárodní harmonizace účetnictví a české účetni standardy (vedoucí: prof. Ing. Libuše Müllerová, CSc.) se zaměřuje na problematiku spojenou s mezinárodní harmonizací účetnictví a s českými účetními standardy. Jejím cílem je sledovat a aktivně ovlivňovat úroveň harmonizace českého účetního prostředí s vyspělým světem, připravit české podniky na zavedení mezinárodních standardů účetního výkaznictví do praxe a analyzovat dopady plynoucí ze zavedení těchto standardů jak v České republice, tak i v dalších evropských zemích. Druhá podskupina Audit (vedoucí: doc. Ing. Vladimír Králíček, CSc.) analyzuje současný stav auditu v České republice a projevy chování auditorských společností. Předmětem výzkumu jsou i otázky spojené s řešením etických problémů této profese. Třetí podskupina Fúze a akvizice (vedoucí: prof. Ing. Hana Vomáčková, CSc.) se věnuje rozboru způsobů oceňování, vykazování a postupy účtování při fúzích, transakcích vkladu podniku, prodeje podniku a jiných přeměn obchodních společností. Dále sleduje i současné tendence ve spojování podniků. Čtvrtá podskupina Účetnictví neziskových organizaci (vedoucí: doc. Ing. Štěpánka Nováková, CSc.) se soustředí na oblast účetnictví neziskových organizací $\mathrm{s}$ cílem aktivně ovlivňovat úroveň mezinárodní harmonizace a české účetní legislativy pro neziskové organizace. Pátá podskupina Informatizace v účetnictví (vedoucí: Ing. Ladislav Mejzlík, Ph.D.) pracuje na vytvoření modelu informačního systému podniku se zvláštním zřetelem na finanční výkaznictví. Dílčí cíl představuje zpracování požadavků na zveřejňování účetních informací na internetu výhledově ve formě standardů. 
Výzkum třetí pracovní skupiny Manažerské účetnictví (vedoucí: prof. Ing. Bohumil Král, CSc.) se orientuje na tvorbu a využití manažersky orientovaných informačních systémů, které by měly zvýšit vypovídací schopnost manažerského účetnictví a zlepšit informační podporu pro potřeby strategického řízení podniků. Ke splnění tohoto cíle je nutné mimo jiné rozpoznat základní rysy chování podniku v tržní ekonomice, vymezit důležité předpoklady transformace podnikového chování na strategické cílové dominanty, vyjádřit vliv těchto předpokladů na organizační, plánovací, kontrolní a informační funkci systému ř́zení, vymezit požadavky na racionální tvorbu a využití systému podnikových politik, plánů, rozpočtů a kalkulací jako nástrojů strategického řízení podniku, a konečně zhodnotit, jak jejich účinnému fungování mohou přispět nástroje a metody tzv. strategicky orientovaného manažerského účetnictví.

Čtvrtá skupina Finance a oceňování podniku (vedoucí: prof. Ing. Miloš Mařík, CSc.) se skládá ze čtyř pracovních podskupin. První podskupina Dlouhodobý finanční management (vedoucí: prof. Ing. Josef Valach, CSc.) se ve svém výzkumu zabývá možnostmi stimulace investičních aktivit a možnostmi postupu řízení ve finanční krizi. Současně se věnuje i tvorbě modelů optimalizace finanční struktury na základě rozboru standardních i nestandardních finančních zdrojů. Druhá podskupina Krátkodobý finanční management (vedoucí: doc. Ing. Petr Marek, CSc.) si klade za cíl vytvořit teoretické základy treasury managementu v českém prostředí a vytvořit odpovídající modely řízení zásob, pohledávek a peněžních prostředků. Do jejího výzkumu spadají i problémy spojené s řízením likvidity a pracovního kapitálu. Třetí podskupina Finanční analýza a plánování (vedoucí: Ing. Jaroslava Holečková, Ph.D.) provádí průběžnou analýzu finančního hospodaření českých podniků. Do jejího výzkumu současně patří i konstrukce modelů finančních ukazatelů, pyramidálních, bonitních a bankrotních, testování vypovídací schopnosti klasických a moderních ukazatelů a tvorba metodiky sestavování finančního plánu v různých časových horizontech. Čtvrtá podskupina Oceňováni podniku a jeho majetku (vedoucí: prof. Ing. Miloš Mařík, CSc.) se soustředí na zpracování návrhu komplexního systému modelů a doporučených postupů pro oceňování podniku a navazujících národních oceňovacích standardů. Rovněž analyzuje dopady, které vyplývají ze zavedení mezinárodních oceňovacích účetních standardů do českého prostředí, a vyhodnocuje chyby v posudcích odhadců majetku.

V rámci výzkumného záměru jsou připravovány dva časopisy. Vedle Českého finančního a účetního časopisu je to i European Financial and Accounting Journal, který je vydáván $\mathrm{v}$ anglické jazykové mutaci. Naším cílem je postupně vytvořit z tohoto časopisu mezinárodně uznávaný časopis pro finanční a účetní problematiku. Rovněž tento časopis je vydávaný v kombinované tištěné a elektronické podobě. Elektronická podoba časopisu se nachází na adrese:

\section{$<$ http://www.efaj.eu>.}

Články jsou na internet umístěny v pdf formátu a jsou volně stažitelné. Na těchto stránkách lze rovněž nalézt Instructions for Authors (pokyny pro autory), Sample paper (vzorový př́ispěvek), License Agreement (formulář licenční smlouvy) a stručný profil členů redakční rady (Editorial Board).

Ačkoli jsem před chvíli uvedl, že Český finanční a účetní časopis je vydáván v rámci řešení výzkumného záměru, neznamená to, že by tento časopis byl určen jen pro autory z řad členů řešitelského týmu. Nikoli, redakční rada časopisu velice ráda uvítá zajímavé články i od ostatních autorů. 
P̌̌EDMLUVA - Marek, P.: O Českém finančním a účetním časopisu a o výzkumném záměru Rozvoj účetní a finančni teorie a její aplikace z interdisciplinárního hlediska

Na závěr mi nezbývá než si přát, aby se Vám tento časopis líbil, a aby zde uveřejněné prŕíspěvky byly při Vašem bádání, při Vašem studiu nebo při Vaší práci užitečné.

doc. Ing. Petr Marek, CSc.

předseda redakční rady Českého finančního a účetního časopisu

a řešitel výzkumného záměru

Rozvoj účetní a finanční teorie

a její aplikace $v$ praxi $z$ interdisciplinárního hlediska 